Supplementary Material for:

\title{
North China Craton: the conjugate margin for northwestern Laurentia in Rodinia
}

Jikai Ding ${ }^{1,2}$, Shihong Zhang ${ }^{1 *}$, David A.D. Evans ${ }^{2}$, Tianshui Yang ${ }^{1}$, Haiyan Li ${ }^{1}$,

$$
\text { Huaichun } \mathrm{Wu}^{1} \text {, Jianping } \mathrm{Chen}^{3}
$$

${ }^{1}$ State Key Laboratory of Biogeology and Environmental Geology, China University

of Geosciences, Beijing 100083, China

${ }^{2}$ Department of Earth \& Planetary Sciences, Yale University, New Haven,

Connecticut 06520, USA

${ }^{3}$ School of Earth Sciences and Resources, China University of Geosciences, Beijing

100083, China

This file contains:

Supplementary text

Supplementary figures (Figure DR1, Figure DR2, Figure DR3 and Figure DR4)

Supplementary tables (Table DR1, DR2, DR3)

Supplementary references

\section{SUPPLEMENTARY TEXT}

\section{S1. Laboratory conditions and procedures}

A portable gasoline-powered drill was used to collect the paleomagnetic samples. The samples were then oriented with a magnetic compass, and a solar compass when possible. The difference between the results using the two orientation devices was less than $2^{\circ}$, suggesting no significant local declination anomalies. All the samples were cut 
into 1-3 standard cylinder paleomagnetic specimens in the laboratory.

All samples were subjected to stepwise thermal demagnetization using a TD-48 furnace (internal residual field less than $10 \mathrm{nT}$ ) in $10-70{ }^{\circ} \mathrm{C}$ steps up to $580{ }^{\circ} \mathrm{C}$. Remanence was measured using an AGICO JR-6A spinner magnetometer and a $2 \mathrm{G}$ 755-4K superconducting magnetometer. The demagnetizations and measurements were performed in a shielded chamber with a residual field less than $300 \mathrm{nT}$. Rock magnetic studies were conducted on representative samples to identify the magnetic carriers. Temperature-dependent susceptibility was measured from -192 to $700{ }^{\circ} \mathrm{C}$ (in argon) followed by cooling back to room temperature using a KLY-4S Kappabridge equipped with a CS-3 high temperature furnace apparatus and a CS-L low temperature cryostat apparatus. These experiments were all conducted at the Paleomagnetism and Environmental Magnetism Laboratory (PMEML) of the China University of Geosciences, Beijing (CUGB). A MicroMag Model 3900 Vibrating Sample Magnetometer (VSM) was used for Hysteresis loops and back-field demagnetizations of saturation isothermal remanent magnetization (IRM) at the Institute of Geophysics, China Earthquake Administration.

Vector components were isolated using principal component analysis (Kirschvink, 1980), and the mean directions were calculated using Fisher statistics (Fisher, 1953). Program packages developed by Enkin (1990) and Cogné (2003) were used to analyze the paleomagnetic data. The GPlates freeware package was used to carry out the paleogeographic reconstructions (Williams et al., 2012). The paleosecular variation was calculated using the method of Biggin et al. (2008), and the confidence interval $(1 \sigma)$ 
was calculated using the $n-1$ jackknife method (Efron, 1982).

\section{S2. Rock magnetic results}

The presence of the Hopkinson peak and Curie temperatures around $580{ }^{\circ} \mathrm{C}$ of the thermomagnetic curves suggests that magnetite and/or low-Ti titanomagnetite are the main magnetic carriers in the specimens (Fig. DR1A, C), which is also supported by the Verwey transition (Verwey, 1939) at around $-150{ }^{\circ} \mathrm{C}$ (Fig. DR1A, C). Hysteresis loops of the specimens are "pot bellied" (Fig. DR1A) with saturation below $500 \mathrm{mT}$. Back-field demagnetizations of IRM show that the coercivities for most specimens are less than $30 \mathrm{mT}$ (DR1B, D), implying a low-coercivity component, probably magnetite, as the dominant magnetic carrier in these specimens. On the Day diagram (Day et al., 1977; Dunlop, 2002), most hysteresis data fall in the PSD grain size area (Fig. DR1E) and some plot near the SD grain size area, indicating that PSD and SD grains dominate. In summary, the rock magnetic results demonstrate that the main magnetic carriers in these specimens are PSD and SD magnetite grains.

\section{S3. Baked-contact test}

We conducted two baked-contact tests for two dikes (LL13 and LL18). The two dikes are both about seven meters in width. The baked samples were derived from the baked host rocks at a distance of 10 to $50 \mathrm{~cm}$ from the contact. While the unbaked samples for dike LL13 were about $5 \mathrm{~m}$ from the contact and $400 \mathrm{~m}$ for dike LL18. After stepwise demagnetization up to $580{ }^{\circ} \mathrm{C}$, four samples from the baked gneisses of dike LL18 (Fig. DR2A, B) could isolate an $\mathrm{HC}$ which directs northeast with shallow inclination, which resembling that of dike LL18 (Fig. DR2C). Unfortunately, the samples from the 
unbaked gneisses display scattered demagnetization patterns. So the baked-contact test is inconclusive. And the samples from the host rocks of dike LL13 all show scattered demagnetization patterns.

\section{S4. Paleogeography}

In Figure 4C, D, The connections between Amazonia, Kalahari, Siberia and Laurentia are taken from Li et al. (2008) and Evans et al. (2016a); and the connections between Australia, Tarim and Laurentia were modified after Eyster et al. (2020) and Wen et al. (2018). The West Africa-Amazonia connection was taken from Bispo-Santos et al. (2014). In the $\sim 930$ Ma reconstruction, the position for Congo/SF is constrained by the 920 Ma pole (BA) from Evans et al. (2016b). At ca. 780 Ma, India and South China Block (SCB) are placed around the polar region according to the pole (MAL) of the Malani large igneous province (Meert et al., 2013). The connection of India and South China were taken from Merdith et al. (2017).

\section{SUPPLEMENTARY FIGURES}

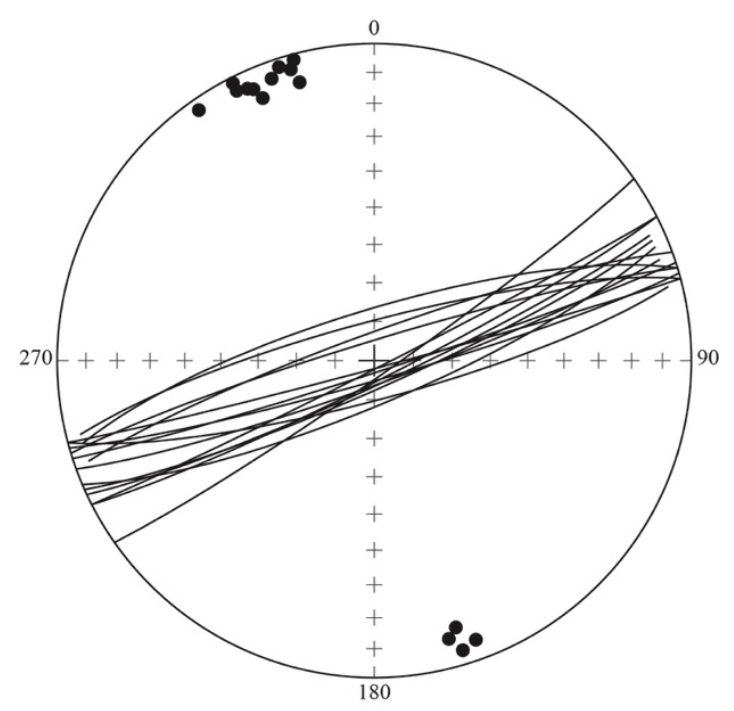

Figure DR1. Lower-hemsphere stereronet projections of the attitudes of dike orientation planes. The dots display the poles of dike orientation planes. 

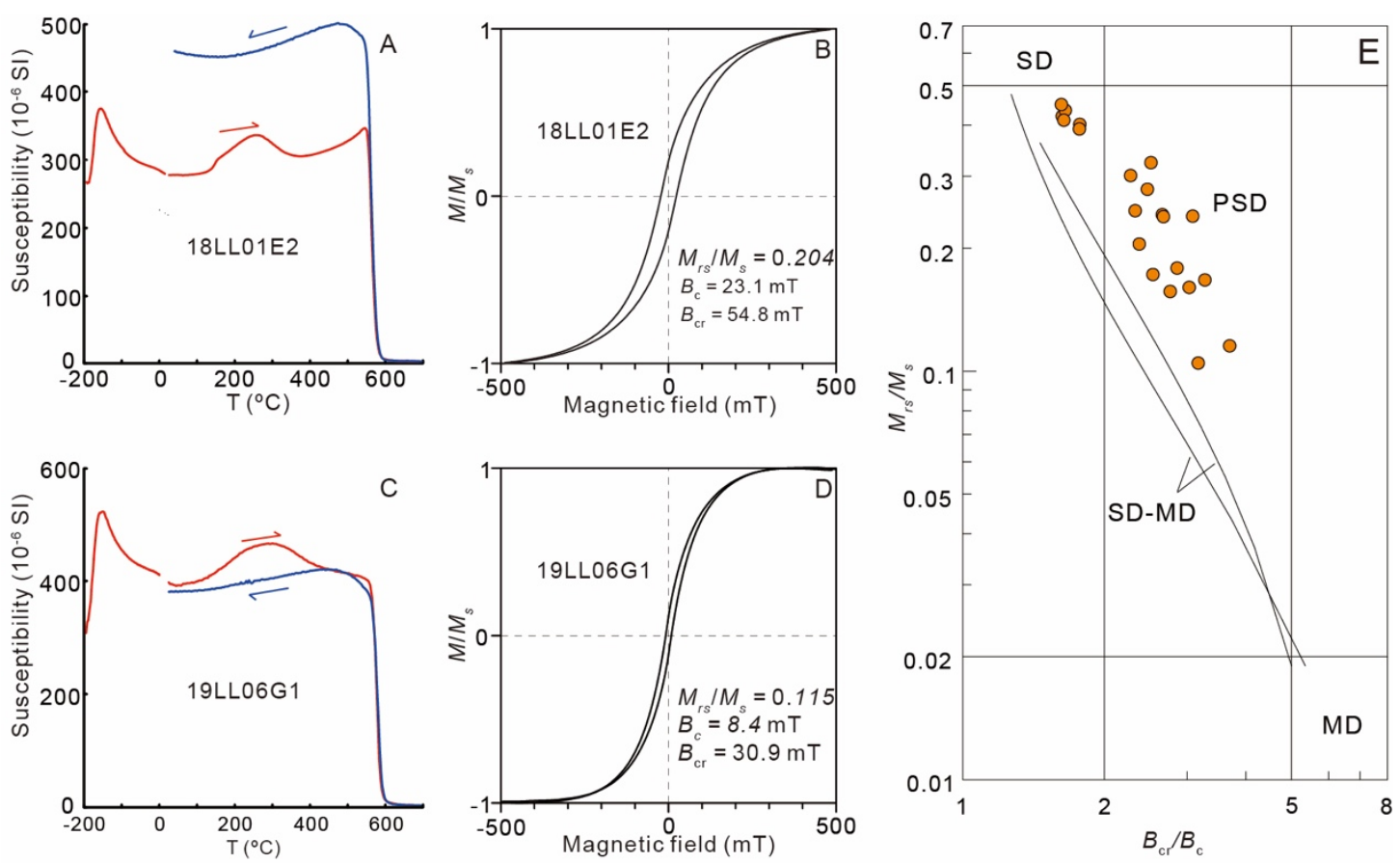

Figure DR2. Rock magnetic results for representative specimens of the $\sim 775$ Ma dikes.

A, C: Low-field magnetic susceptibility versus temperature for heating (red line) and cooling (blue line). B, D: Magnetic hysteresis loops. E: Day plot (Day et al., 1977; Dunlop, 2002) of the hysteresis parameters. Ms, saturation magnetization; Mrs, saturation remanence; Bcr, coercivity of remanence; Bc, coercivity; SD, single-domain; PSD, pseudo-single domain; MD, multidomain. 

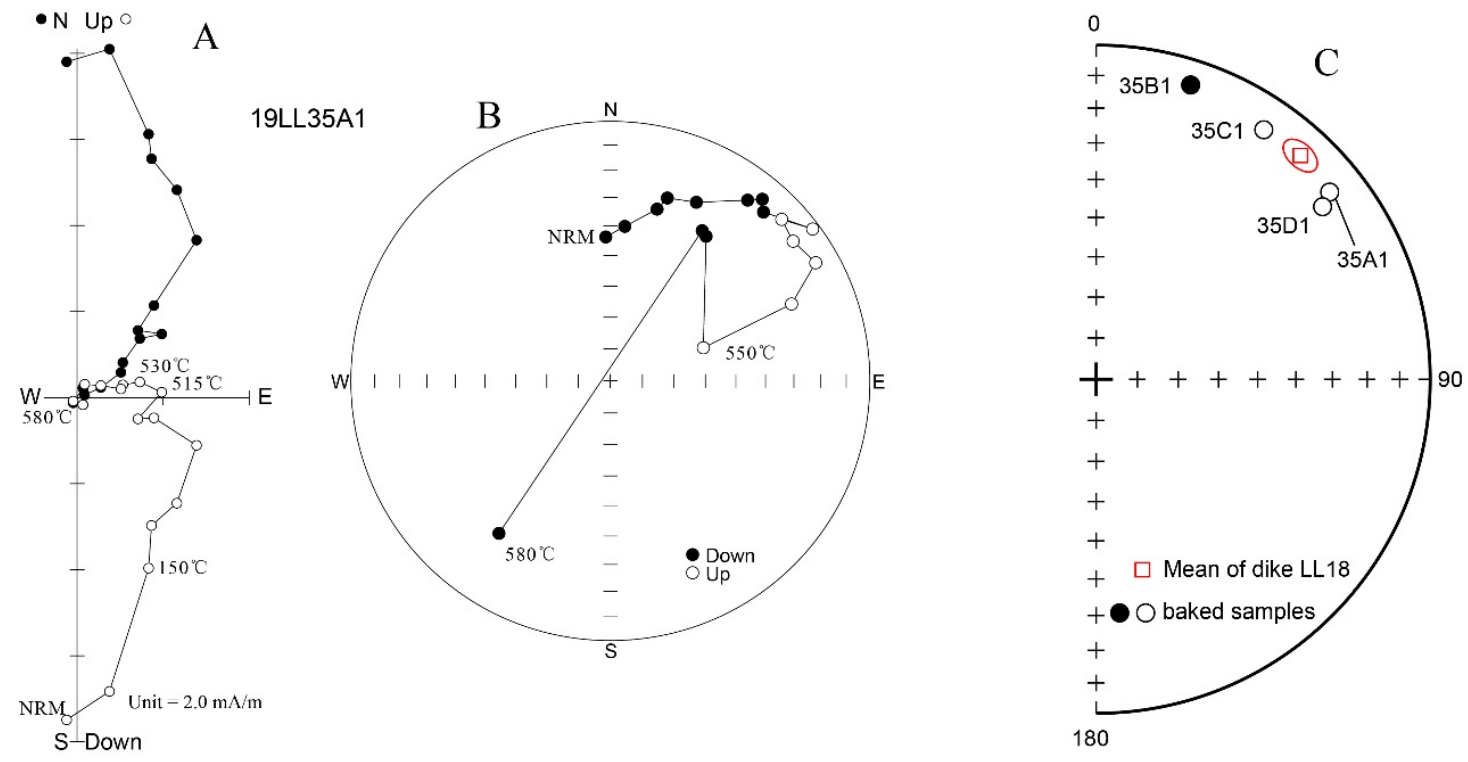

Figure DR3. Orthogonal demagnetization diagram (A) and equal-area projection (B) of the representative specimen from the baked gneisses in geographic coordinates. C: Equal-area projection of the $\mathrm{HC}$ directions of the baked gneisses and the mean $\mathrm{HC}$ direction of dike LL18.

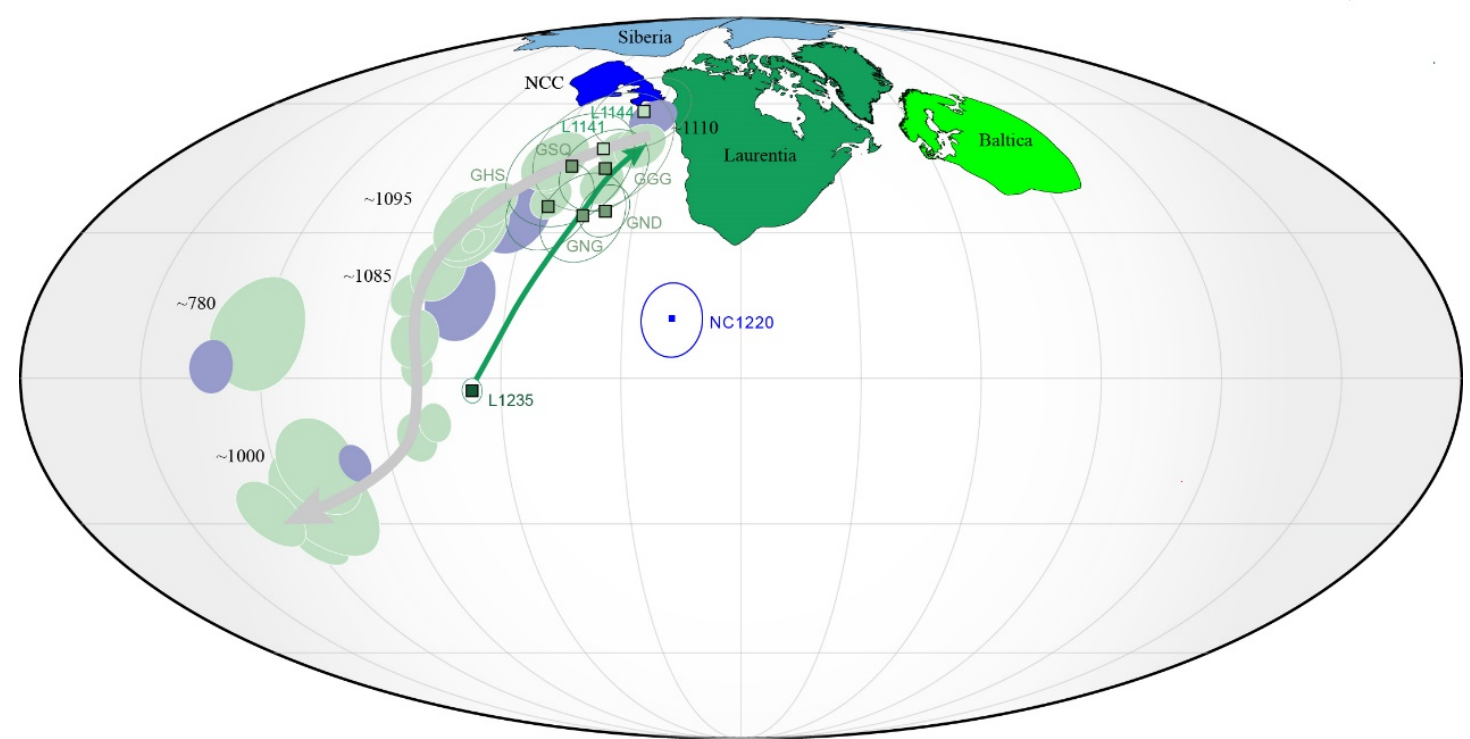

Figure DR4. Comparison of the $\sim 1230-775$ Ma poles of the North China Craton (NCC) and Laurentia (in present North American coordinates). The $1230-1141$ Ma poles are highlighted. The NCC and its poles are rotated to Laurentia using Euler rotation (58 
$\left.30^{\circ}, 68^{\circ}\right)$. The poles are listed in Table DR2.

\section{SUPPLEMENTARY REFERENCES}

Biggin, A.J., Strik, G.H., and Langereis, C.G., 2008, Evidence for a very-long-term trend in geomagnetic secular variation: Nature Geoscience, v. 1, no. 6, p. 395-398.

Bispo-Santos, F., D’Agrella-Filho, M.S., Janikian, L., Reis, N.J., Trindade, R.I., and Reis, M.A.A., 2014, Towards Columbia: Paleomagnetism of 1980-1960 Ma Surumu volcanic rocks, Northern Amazonian Craton: Precambrian Research, v. 244, p. 123-138.

Books, K.G., 1968, Magnetization of the lowermost Keweenawan lava flows in the Lake Superior area: US Geological Survey Professional Paper, v. 600, p. 248-254.

Books, K.G., 1972, Paleomagnetism of some Lake Superior Keweenawan rocks: U.S. Geological Survey Professional Paper, v. 760, 42 p.

Brown, L.L., and McEnroe, S.A., 2004, Palaeomagnetism of the Egersund-Ogna anorthosite, Rogaland, Norway, and the position of Fennoscandia in the Late Proterozoic: Geophysical Journal International, v. 158, no. 2, p. 479-488.

Brown, L., and McEnroe, S., 2012, Paleomagnetism and magnetic mineralogy of Grenville metamorphic and igneous rocks, Adirondack Highlands, USA: Precambrian Research, v. 212, p. 57-74.

Brown, L.L., and McEnroe, S.A., 2015, 916 Ma pole for southwestern Baltica: Palaeomagnetism of the Bjerkreim-Sokndal layered intrusion, Rogaland igneous complex, southern Norway: Geophysical Journal International, v. 203, no. 1, p. 567-587.

Cawood, P.A., Strachan, R., Cutts, K., Kinny, P.D., Hand, M., and Pisarevsky, S., 2010, Neoproterozoic orogeny along the margin of Rodinia: Valhalla orogen, North Atlantic: Geology, v. 38, p. 99-102.

Cogné, J., 2003, PaleoMac: a Macintosh ${ }^{\mathrm{TM}}$ application for treating paleomagnetic data and making plate reconstructions: Geochemistry, Geophysics, Geosystems, v. 4, no. 1 .

Cumming, V.M., Poulton, S.W., Rooney, A.D., and Selby, D., 2013, Anoxia in the terrestrial environment during the late Mesoproterozoic: Geology, v. 41, no. 5, p. $583-586$.

Davis, D., and Sutcliffe, R., 1985, U-Pb ages from the Nipigon plate and northern Lake Superior: Geological Society of America Bulletin, v. 96, no. 12, p. 1572-1579.

Davis, D., and Green, J., 1997, Geochronology of the North American Midcontinent rift in western Lake Superior and implications for its geodynamic evolution: Canadian Journal of Earth Sciences, v. 34, no. 4, p. 476-488.

Day, R., Fuller, M., and Schmidt, V., 1977, Hysteresis properties of titanomagnetites: grain-size and compositional dependence: Physics of the Earth and planetary interiors, v. 13 , no. 4, p. 260-267.

Diehl, J., and Haig, T., 1994, A paleomagnetic study of the lava flows within the Copper Harbor Conglomerate, Michigan: new results and implications: Canadian Journal 
of Earth Sciences, v. 31, no. 2, p. 369-380.

Ding, J., Zhang, S., Zhao, H., Xian, H., Li, H., Yang, T., Wu, H., and Wang, W., 2020, A combined geochronological and paleomagnetic study on $\sim 1220$ Ma mafic dikes in the North China Craton and the implications for the breakup of Nuna and assembly of Rodinia: American Journal of Science, v. 320, no. 2, p. 125-149.

Dudàs, F., Davidson, A., and Bethune, K., 1994, Age of the Sudbury diabase dykes and their metamorphism in the Grenville Province, Ontario: Radiogenic age and isotopic studies: Report, v. 8, p. 97-106.

Dunlop, D.J., 2002, Theory and application of the Day plot (Mrs/Ms versus Hcr/Hc) 1. Theoretical curves and tests using titanomagnetite data: Journal of Geophysical Research: Solid Earth, v. 107, no. B3, p. EPM 4-1-EPM 4-22.

Efron, B., 1982, The jackknife, the bootstrap and other resampling plans: Vermont, Capital City Press, 93 p.

Elming, S.Å., Pisarevsky, S.A., Layer, P., and Bylund, G., 2014, A palaeomagnetic and ${ }^{40} \mathrm{Ar} /{ }^{39} \mathrm{Ar}$ study of mafic dykes in southern Sweden: A new Early Neoproterozoic key-pole for the Baltic Shield and implications for Sveconorwegian and Grenville loops: Precambrian Research, v. 244, no. 1, p. 192-206.

Enkin, R., 1990, The direction-correction test for paleomagnetism: Thesis, Universite de Paris.

Ernst, R. and Buchan, K., 1993, Paleomagnetism of the Abitibi dike swarm, southern Superior Province, and implications for the Logan Loop: Canadian Journal of Earth Science, v. 30, p. 1886-1897.

Evans, D.A.D., 2009, The palaeomagnetically viable, long-lived and all-inclusive Rodinia supercontinent reconstruction: Geological Society, London, Special Publications, v. 327, no. 1, p. 371-404.

Evans, D.A.D., Veselovsky, R.V., Petrov, P.Y., Shatsillo, A.V., and Pavlov, V.E., 2016a, Paleomagnetism of Mesoproterozoic margins of the Anabar Shield: A hypothesized billion-year partnership of Siberia and northern Laurentia: Precambrian Research, v. 281, p. 639-655.

Evans, D.A.D., Trindade, R.I.F., Catelani, E.L., D'Agrella-Filho, M.S., Heaman, L.M., Oliveira, E.P., Söderlund, U., Ernst, R.E., Smirnov, A.V., and Salminen, J.M., 2016b, Return to Rodinia? Moderate to high palaeolatitude of the São Francisco/Congo craton at 920 Ma: Geological Society, London, Special Publications, v. 424, no. 1, p. 167-191.

Eyster, A., Weiss, B.P., Karlstrom, K., and Macdonald, F.A., 2020, Paleomagnetism of the Chuar Group and evaluation of the late Tonian Laurentian apparent polar wander path with implications for the makeup and breakup of Rodinia: GSA Bulletin, v. 132, no. 3-4, p. 710-738.

Fairchild, L.M., Swanson-Hysell, N.L., Ramezani, J., Sprain, C.J., and Bowring, S.A., 2017, The end of Midcontinent Rift magmatism and the paleogeography of Laurentia: Lithosphere, v. 9, no. 1, p. 117-133.

Fisher, R.A., 1953, Dispersion on a sphere: Proceedings of the Royal Society of London. Series A. Mathematical and Physical Sciences, v. 217, no. 1130, p. 295-305.

Fu, X., Zhang, S., Li, H., Ding, J., Yang, T., Wu, H., Yuan, H., and Lv, J., 2015, New 
paleomagnetic results from the Huaibei Group and Neoproterozoic mafic sills in the North China Craton and their paleogeographic implications: Precambrian Research, v. 269, p. 90-106.

Gong, Z., Evans, D.A.D., Elming, S.Å., Söderlund, U., and Salminen, J.M., 2018, Paleomagnetism, magnetic anisotropy and $\mathrm{U}-\mathrm{Pb}$ baddeleyite geochronology of the early Neoproterozoic Blekinge-Dalarna dolerite dykes, Sweden: Precambrian Research, v. 317, p. 14-32.

Gregory, L.C., Meert, J.G., Bingen, B., Pandit, M.K., and Torsvik, T.H., 2009, Paleomagnetism and geochronology of the Malani igneous suite, Northwest India: Implications for the configuration of Rodinia and the assembly of Gondwana: Precambrian Research, v. 170, no. 1-2, p. 13-26.

Halls, H., 1974, A paleomagnetic reversal in the Osler Volcanic Group, northern Lake Superior: Canadian Journal of Earth Sciences, v. 11, no. 9, p. 1200-1207.

Halls, H., and Pesonen, L., 1982, Paleomagnetism of Keweenawan rocks: Geol. Soc. Am. Mem, v. 156, p. 173-201.

Halls, H. C., Lovette, A., Hamilton, M., and Söderlund, U., 2015, A paleomagnetic and $\mathrm{U}-\mathrm{Pb}$ geochronology study of the western end of the Grenville dyke swarm: Rapid changes in paleomagnetic field direction at ca. 585 Ma related to polarity reversals?: Precambrian Research, v. 257, p. 137-166.

He, T., Zhou, Y., Vermeesch, P., Rittner, M., Miao, L., Zhu, M., Carter, A., von Strandmann, P.A.P., and Shields, G.A., 2017, Measuring the 'Great Unconformity' on the North China Craton using new detrital zircon age data: Geological Society, London, Special Publications, v. 448, no. 1, p. 145-159.

Henry, S.G., Mauk, F.J., and Van der Voo, R., 1977, Paleomagnetism of the upper Keweenawan sediments: the Nonesuch Shale and Freda Sandstone: Canadian Journal of Earth Sciences, v. 14, no. 5, p. 1128-1138.

Hnat, J.S., Van der Pluijm, B.A., and Van der Voo, R., 2006, Primary curvature in the Mid-Continent Rift: Paleomagnetism of the Portage Lake Volcanics (northern Michigan, USA): Tectonophysics, v. 425, no. 1-4, p. 71-82.

Kean, W., Williams, I., Chan, L., and Feeney, J., 1997, Magnetism of the Keweenawan age Chengwatana lava flows, northwest Wisconsin: Geophysical Research Letters, v. 24 , no. 12 , p. $1523-1526$.

Kirschvink, J., 1980, The least-squares line and plane and the analysis of palaeomagnetic data: Geophysical Journal International, v. 62, no. 3, p. 699-718.

Krogh, T. E., Corfu, F., Davis, D. W., Dunning, G. R., Heaman, L. M., Kamo, S. L. Machado, N., Greenough, J.D., and Nakamura, E., 1987, Precise U-Pb isotopic ages of diabase dykes and mafic to ultramafic rocks using trace amounts of baddeleyite and zircon. In H. C. Halls and W. F. Fahrig (Eds.), Mafic dyke swarms: Geological Association of Canada, Special Paper, v. 34, p. 147-152.

Kulakov, E.V., Smirnov, A.V., and Diehl, J.F., 2013, Paleomagnetism of 1.09 Ga Lake Shore Traps (Keweenaw Peninsula, Michigan): new results and implications: Canadian Journal of Earth Sciences, v. 50, no. 11, p. 1085-1096.

Li, Z.X., Bogdanova, S.V., Collins, A.S., Davidson, A., De Waele, B., Ernst, R.E., Fitzsimons, I.C.W., Fuck, R. A., Gladkochub, D.P., Jacobs, J., Karlstrom, K.E., Lu, 
S., Natapov, L.M., Pease, V., Pisarevsky, S.A., Thrane, K., and Vernikovsky, V., 2008, Assembly, configuration, and break-up history of Rodinia: A synthesis: Precambrian Research, v. 160, no. 1-2, p. 179-210.

Li, Z.X., and Evans, D.A.D., 2011, Late Neoproterozoic $40^{\circ}$ intraplate rotation within Australia allows for a tighter-fitting and longer-lasting Rodinia: Geology, v. 39, no. 1, p. 39-42.

McCabe, C., and Van der Voo, R., 1983, Paleomagnetic results from the upper Keweenawan Chequamegon Sandstone: implications for red bed diagenesis and Late Precambrian apparent polar wander of North America: Canadian Journal of Earth Sciences, v. 20, no. 1, p. 105-112.

McElhinny, M.W., Powell, C.M., and Pisarevsky, S.A., 2003, Paleozoic terranes of eastern Australia and the drift history of Gondwana: Tectonophysics, v. 362, no. 1-4, p. 41-65.

Meert, J.G., Pandit, M.K., and Kamenov, G.D., 2013, Further geochronological and paleomagnetic constraints on Malani (and pre-Malani) magmatism in NW India: Tectonophysics, v. 608, p. 1254-1267.

Merdith, A.S., Collins, A.S., Williams, S.E., Pisarevsky, S., Foden, J.D., Archibald, D.B., Blades, M.L., Alessio, B.L., Armistead, S., Plavsa, D., Clark, C., and Müller, R.D., 2017, A full-plate global reconstruction of the Neoproterozoic: Gondwana Research, v. 50, p. 84-134.

Milton, J.E., Hickey, K.A., Gleeson, S.A., and Friedman, R.M., 2017, New U-Pb constraints on the age of the Little Dal Basalts and Gunbarrel-related volcanism in Rodinia: Precambrian Research, v. 296, p. 168-180.

Palmer, H., Merz, B., and Hayatsu, A., 1977, The Sudbury dikes of the Grenville Front region: paleomagnetism, petrochemistry, and $\mathrm{K}-\mathrm{Ar}$ age studies: Canadian Journal of Earth Sciences, v. 14, no. 8, p. 1867-1887.

Payne, J.L., Hand, M., Barovich, K.M., Reid, A., and Evans, D.A.D., 2009, Correlations and reconstruction models for the 2500-1500 Ma evolution of the Mawson Continent: Geological Society, London, Special Publications, v. 323, no. 1, p. 319355.

Piispa, E. J., Smirnov, A. V., Pesonen, L. J., and Mitchell, R. H., 2018, Paleomagnetism and geochemistry of $1144 \mathrm{Ma}$ lamprophyre dikes, Northwestern Ontario: Implications for the North American polar wander and plate velocities: Journal of Geophysical Research: Solid Earth, v. 123, p. 6195-6214.

Piper, J. D. A., 1977, Palaeomagnetism of the giant dykes of Tugtutoq and Narssaq Gabbro, Gardar Igneous Province, South Greenland: Bulletin of the Geological Society of Denmark, v. 26, p. 85-94.

Piper, J.D.A., 1992, The palaeomagnetism of major (Middle Proterozoic) igneous complexes. South Greenland and the Gardar apparent polar wander track: Precambrian Research, v. 54, p. 153-172.

Powell, C., and Li, Z.X., 1994, Reconstruction of the Panthalassan margin of Gondwanaland Permian-Triassic pangean basins and foldbelts along the Panthalassan margin of Gondwanaland: Geological Society of America Memoir, v. 184 , p. 5-9. 
Queen, M., Hanes, J. A., Archibald, D. A., Heaman, L. M., Hanes, J. A., Archibald, D. A., and Farrar, E., 1996, ${ }^{40} \mathrm{Ar} /{ }^{39} \mathrm{Ar}$ phlogopite and $\mathrm{U}-\mathrm{Pb}$ perovskite dating of lamprophyre dykes from the eastern Lake Superior region: Evidence for a $1.14 \mathrm{Ga}$ magmatic precursor to Midcontinent Rift volcanism: Canadian Journal of Earth Sciences, v. 33, no. 6, p. 958-965.

Roest, W.R., and Srivastava, S.P., 1989, Seafloor spreading in the Labrador Sea: a new reconstruction: Geology, v. 17, p. 1000-1004.

Roy, J., and Robertson, W., 1978, Paleomagnetism of the Jacobsville Formation and the apparent polar path for the interval $\sim 1100$ to $\sim 670$ m.y. for North America: Journal of Geophysical Research: Solid Earth, v. 83, no. B3, p. 1289-1304.

Stearn, J., and Piper, J., 1984, Palaeomagnetism of the Sveconorwegian mobile belt of the Fennoscandian Shield: Precambrian Research, v. 23, no. 3-4, p. 201-246.

Swanson-Hysell, N.L., Burgess, S.D., Maloof, A.C., and Bowring, S.A., 2014a, Magmatic activity and plate motion during the latent stage of Midcontinent Rift development: Geology, v. 42, no. 6, p. 475-478.

Swanson-Hysell, N.L., Vaughan, A.A., Mustain, M.R., and Asp, K.E., 2014b, Confirmation of progressive plate motion during the Midcontinent Rift's early magmatic stage from the Osler Volcanic Group, Ontario, Canada: Geochemistry, Geophysics, Geosystems, v. 15, no. 5, p. 2039-2047.

Swanson-Hysell, N.L., Ramezani, J., Fairchild, L.M., and Rose, I.R., 2019, Failed rifting and fast drifting: Midcontinent Rift development, Laurentia's rapid motion and the driver of Grenvillian orogenesis: GSA Bulletin, v. 131, no. 5-6, p. 913940.

Symons, D., Kawasaki, K., and Diehl, J., 2013, Age and genesis of the White Pine stratiform copper mineralization, northern Michigan, USA, from paleomagnetism: Geofluids, v. 13, no. 2, p. 112-126.

Tauxe, L., and Kodama, K.P., 2009, Paleosecular variation models for ancient times: Clues from Keweenawan lava flows: Physics of the Earth and Planetary Interiors, v. 177, no. 1-2, p. 31-45.

Upton, B.G.J., Emeleus, C.H., Heaman, L.M., Goodenough, K.M., and Finch, A., 2003, Magmatism of the mid-Proterozoic Gardar Province, South Greenland: chronology, petrogenesis and geological setting: Lithos, v. 68, p. 43-65.

Verwey, E., 1939, Electronic conduction of magnetite (Fe3O4) and its transition point at low temperatures: Nature, v. 144, no. 3642, p. 327-328.

Walderhaug, H.J., Torsvik, T.H., Eide, E.A., Sundvoll, B., and Bingen, B., 1999, Geochronology and palaeomagnetism of the Hunnedalen dykes, SW Norway: implications for the Sveconorwegian apparent polar wander loop: Earth and Planetary Science Letters, v. 169, no. 1-2, p. 71-83.

Walderhaug, H.J., Torsvik, T.H., and Halvorsen, E., 2007, The Egersund dykes (SW Norway): A robust early Ediacaran (Vendian) palaeomagnetic pole from Baltica: Geophysical Journal International, v. 168, no. 3, p. 935-948.

Wang, C., Peng, P., Wang, X., and Yang, S., 2016, Nature of three Proterozoic (1680Ma, $1230 \mathrm{Ma}$ and $775 \mathrm{Ma}$ ) mafic dyke swarms in North China: Implications for tectonic evolution and paleogeographic reconstruction: Precambrian Research, v. 285, p. 
$109-126$.

Wang, Q., Yang, D., and Xu, W., 2012, Neoproterozoic basic magmatism in the southeast margin of North China Craton: Evidence from whole-rock geochemistry, $\mathrm{U}-\mathrm{Pb}$ and $\mathrm{Hf}$ isotopic study of zircons from diabase swarms in the Xuzhou-Huaibei area of China: Science China Earth Sciences, v. 55, no. 9, p. 1461-1479.

Wang, W., Liu, S., Santosh, M., Zhang, L., Bai, X., Zhao, Y., Zhang, S., and Guo, R., 2015, 1.23 Ga mafic dykes in the North China Craton and their implications for the reconstruction of the Columbia supercontinent: Gondwana Research, v. 27, no. 4, p. 1407-1418.

Warnock, A.C., Kodama, K.P., and Zeitler, P.K., 2000, Using thermochronometry and low - temperature demagnetization to accurately date Precambrian paleomagnetic poles: Journal of Geophysical Research: Solid Earth, v. 105, no. B8, p. 1943519453.

Weil, A.B., Geissman, J.W., Heizler, M., and Van der Voo, R., 2003, Paleomagnetism of middle Proterozoic mafic intrusions and upper Proterozoic (Nankoweap) red beds from the lower Grand Canyon Supergroup, Arizona: Tectonophysics, v. 375, no. 1-4, p. 199-220.

Williams, S.E., Muller, R.D., Landgrebe, T.C., and Whittaker, J., 2012, An open-source software environment for visualizing and refining plate tectonic reconstructions using high-resolution geological and geophysical data sets: GSA Today, v. 22, no. 4-5, p. 4-9.

Yang, D., Xu, W., Xu, Y., Wang, Q., Pei, F., and Wang, F., 2012, U-Pb ages and Hf isotope data from detrital zircons in the Neoproterozoic sandstones of northern Jiangsu and southern Liaoning Provinces, China: implications for the Late Precambrian evolution of the southeastern North China Craton: Precambrian Research, v. 216, p. 162-176.

Zartman, R.E., Nicholson, S.W., Cannon, W. F., and Morey, G., 1997, U-Th-Pb zircon ages of some Keweenawan Supergroup rocks from the south shore of Lake Superior: Canadian Journal of Earth Sciences, v. 34, no. 4, p. 549-561.

Zhao, H., Zhang, S., Ding, J., Chang, L., Ren, Q., Li, H., Yang, T., and Wu, H., 2020, New geochronologic and paleomagnetic results from early Neoproterozoic mafic sills and late Mesoproterozoic to early Neoproterozoic successions in the eastern North China Craton, and implications for the reconstruction of Rodinia: GSA Bulletin, v. 132, no. 3-4, p. 739-766. 